Article

\title{
Tourist Mobility at the Destination Toward Protected Areas: The Case-Study of Extremadura
}

\author{
José Manuel Sánchez Martín $1, * \mathbb{C}$, Juan Ignacio Rengifo Gallego ${ }^{2} \mathbb{C}$ and \\ Luz María Martín Delgado ${ }^{1}$ (D) \\ 1 Faculty of Business and Tourism, University of Extremadura, 10071 Caceres, Spain; luzmariamd@unex.es \\ 2 Faculty of Letters, University of Extremadura, 10071 Caceres, Spain; irengifo@unex.es \\ * Correspondence: jmsanche@unex.es
}

Received: 8 November 2018; Accepted: 13 December 2018; Published: 19 December 2018

check for updates

\begin{abstract}
The use of natural protected areas has been analyzed abundantly in the relevant literature, although on many occasions these areas are studied from the viewpoint of their role as a tourist destination in themselves, while neglecting their role as a tourist attraction that can be visited from the main destination of their stay. In certain specific areas, as in the case of Extremadura, protected areas are often a complementary destination for visitors who are staying in popular tourist hubs. This study is based on data from 4 different spaces (with different degrees in their status as protected areas) about the flow of tourists they generate at the destination. In light of the data, this paper identifies the 41 towns and villages with the most tourists, later to determine their mobility towards natural protected areas. Information was collected from almost 14,000 surveys that were filled at 52 tourist offices. This information allowed us to map the flow of tourists from their places of stay to the protected areas analyzed here, which resulted in the mapping of relevant networks by means of a Geographic Information System following the criterion of shortest path available. The results here clearly demonstrate that each area has a varying capacity to attract visitors, although in a large proportion of cases, the 60-min isochrone is a boundary beyond which the number of visitors drops significantly.
\end{abstract}

Keywords: protected natural areas; Extremadura; tourist flow; mobility at the destination

\section{Introduction}

The concept of Natural Protected Area (NPA-ENP, in Spanish initials) has evolved noticeably in Spain. The most widespread definition for the term is that of an area where human activity has not altered the typical environment drastically, and, as a consequence, has allowed for biotic and abiotic elements to be preserved in good condition. Several experts have characterized these areas along these lines in studies from decades ago [1,2] and in more recent times [3-5]. These areas constitute special elements within the broader category of rural areas [6,7], which has called for specific legal protection.

Despite the many disquisitions about these areas in the relevant legislation-such as the Ley 4/1989 on the Conservation of Natural Areas and Wildlife, later replaced by Ley 42/2007 on Natural Heritage and Biodiversity, as well as many other further modifications-all these pieces of legislation share one common defining concept, that of Natural Protected Areas. In this regard, Ley 42/2007 contains perhaps the widest definition of this concept that is still in effect. Namely, article 28 defines protected areas, as follows: "the areas of the national territory (including continental waters and seawaters, together with the exclusive economic zone and the continental shelf) that meet at least one of the following criteria and are recognized as such: (a) it contains natural elements or systems that are representative, unique, fragile, endangered, or with a special value because of their ecological, scientific, landscape, geological, or educational characteristics; (b) they are specifically used for the 
conservation of biodiversity, geodiversity, and their related natural and cultural resources". The fact that these areas are protected by law is obvious in the legislation. However, article 4 Section 1 of this law states that "natural resources and biodiversity play an important social role because of their close link with human development, health and welfare, and because of their fundamental function as the basis of social and economic development". Thus, the law itself acknowledges, however implicitly, that the conservation of natural resources and socioeconomic development must go hand in hand in a way that allows for the sustainability not only of the environment, but also of the society that lives in it, which in turn necessitates the economic benefits that may derive from the said environment.

The above law also establishes in article 51 a National Inventory of Natural Protected Areas, the Red Natura 2000 network, and the Areas protected by international institutions, all under the auspices of the Ministry of Environment (Medio Ambiente)—although each region is responsible for providing the necessary information to keep this inventory up to date. The inventory took effect through the Royal Decreee (Real Decreto) 556/2011 on the 12th May 2011. This allowed the public to retrieve factual, reliable information that can be compared between regions on a national level. This, in turn, led to the creation of an Integrated System of Information, the Nature Database (Banco de Datos de la Naturaleza), which was implemented in order to analyze and circulate the available information [8].

As far as Extremadura is concerned, the first section of article 15 of Ley 8/1998—on environmental conservation and the natural protected areas of Extremadura-specifies that "the Natural Protected Areas of the Autonomous Region of Extremadura are those that may be awarded said denomination by virtue of this law, because of their singularity, uniqueness, fragility, or the interest of its natural systems. In the interest of sustainability, these areas will be regulated by special legislation so as to enforce the protection and conservation of their biodiversity and the natural and cultural resources thereof". Likewise, article 16 of the same law tipifies protected areas, among whose categories we may find: “(a) Natural Parks; (b) Natural Reservations; (c) Natural Monuments; (d) Protected Landscapes; (e) Special Areas of Conservation; (f) Environmental and Biodiversity Passage Areas; (g) Peripheral Urban Parks of Conservation and Leisure; (h) Places of Scientific Interest; (i) Unique Trees; and, (j) Ecocultural Zones". However, this pioneering law in Extremadura has been revised and modified on a number of occasions (e.g., Ley 9/2006 modifiying Ley 8/1998 on environmental conservation and the natural protected areas of Extremadura). According to this latest modification, the Network of Protected Areas of Extremadura now comprises-in addition to the aforementioned denominations-the European Environmental Network NATURA 2000 (Areas of Special Conservational Purposes for Birds, Places of Importance for the Community, and Areas of Special Conservation) as well as other specific conservational denominations (Monfragüe National Park; Monfragüe Biosphere Reservation; International Tajo-Tejo Transnational Biosphere Reservation; Private Areas of Environmental Interest and Ramsar Sites).

Among the main goals under article 2 of Ley 8/1998 and later revisions, we find: (d) improving the welfare and economic development of the human population associated to the protected areas and their areas of socioeconomic influence; (f) the sustainable use of natural resources. All of these goals, covered by the law itself, insist on the need to make the most of these areas in order to obtain social and economic benefits. In this regard, this paper analyzes the use that these areas have been made of for tourist purposes.

In light of the above, the law itself clearly advocates for the need to make the most of these areas in order to obtain social and economic benefits. In this regard, the present study seeks to analyze the use that is made of these areas for touristic purposes by assessing their capacity to attract visitors.

The tendency to acknowledge natural protected areas as a tourist destination has a long tradition in the relevant literature-from a wide variety of viewpoints and geographic scopes [9-17], yet rarely is their capacity to attract visitors analyzed [18].

Despite the obvious importance that natural protected areas have for tourism, the National Park Network, the flagship of protected areas, simply records the number of visitors to each park, without 
any further data about the demand generated by these areas. Despite these limitations, the way these protected areas have developed and the sheer number of visitors they welcome is a clear indication of their potential as tourist attractions. According to this source, in 1996, the 11 Spanish National Parks received almost 8.5 million visitors; by 2017, the 15 parks comprising the network now are close to 15.5 million visitors. This is to say, there is an obvious growing tendency, which may be said to have begun in 2013, when the number of parks reached the present day figure of 15 [19]. In the last five years, visitors have increased by more than 30\%-from 11.6 million to 15.4 million (Figure 1 ). However promising the outlook may be for National Parks, it must be noted that there exist many other typologies for protected areas, some of which are narrowly focused on specific niches in the tourist market. For example, we can mention Geoparques (the main destination for geogolical tourism), the ZEPAS, which are oriented towards birdwatching, and so on. However, many of these do not have reliable sources that would allow us to have an approximate idea of the number of visitors they receive-not to mention how their demand is structured. Still, there are many examples in the relevant literature that suggest that natural areas are true tourist resources that may contribute to develop and diversify the economy of rural areas $[6,20,21]$. Nevertheless, they also underscore a certain degree of reluctance towards this phenomenon because of the negative impacts it may have, which is why they also express the need to promote tourist policies that go hand in hand with sustainability [22,23].

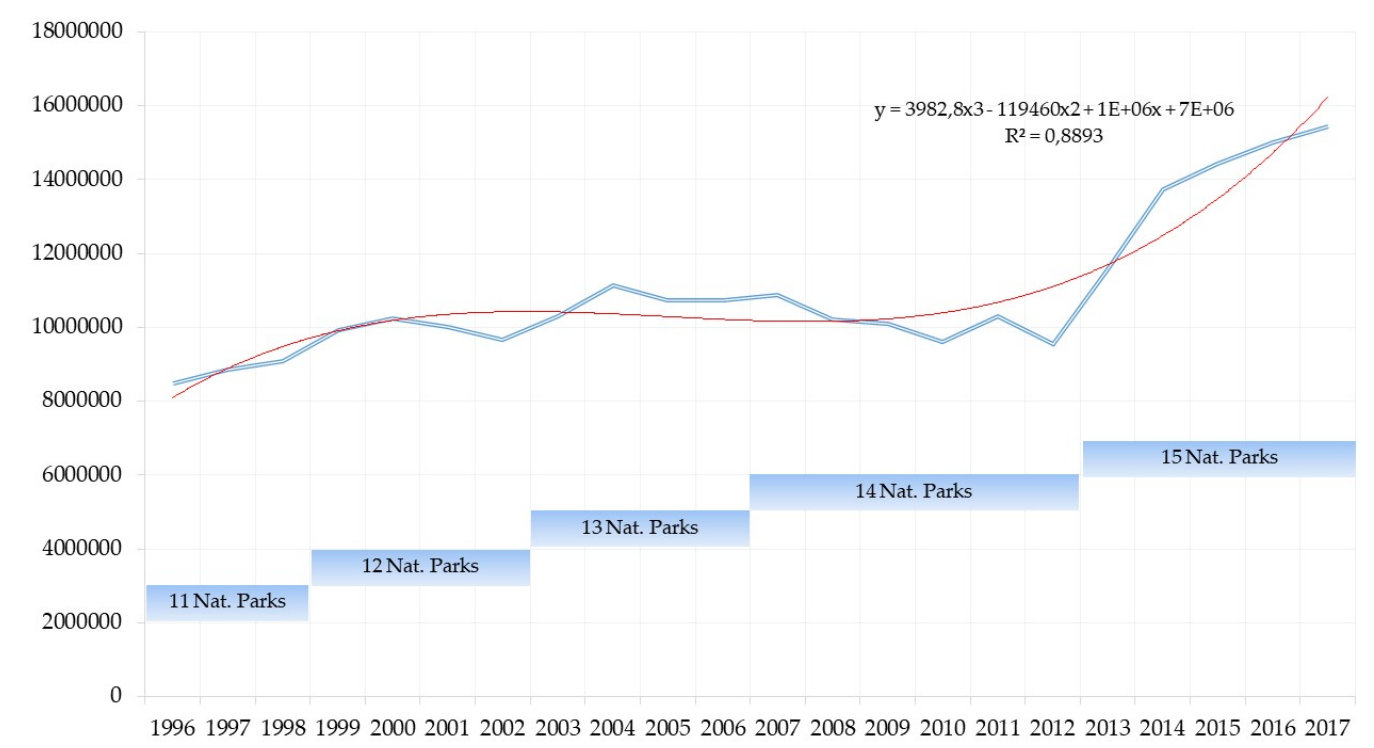

Figure 1. Number of visitors to National Parks by year. Source: National Parks Network.

This is why we find it necessary to ascertain the capacity to attract tourists of these areas, which begs the question of whether natural protected areas do indeed attract a number of visitors that is large enough. This would facilitate the decision-making process in the making of the policies that may, in turn, be implemented in those areas.

In line with the questions above, the main research purpose of this study is to determine whether the key protected areas in Extremadura can potentially attract enough visitors, so as to encourage the development of ecotourism. This main purpose is inextricably linked to others, such as finding out what is the reach of the tourist pull of these areas or whether there exist elements that may influence the predictable tourist potential of these areas. All of this suggests that this research should serve as the basis for devising a strategic plan focused on these areas in order to promote the niche of ecotourism in Extremadura.

The structure of this paper also includes other four sections-in addition to this succinct introduction where matters of legislation and the potential that protected areas may have for tourism have been addressed. These sections focus on the materials and methodology that have been used: 
the area of study as well as the data and the method of analysis are outlined. Other sections include a description and analysis of the results, as well as a discussion and conclusions thereof.

\section{Mobility Toward Natural Protected Areas}

The recreational potential of natural protected areas has long been acknowledged in the Spanish context. These spaces have generated a remarkable flow of visitors who are attracted by their pristine environment. This, in turn, has set the tone for a growing mobility from major urban areas toward these areas [24]. The widespread profitable use of natural areas gave rise to a growing scholarly interest in the planning of visits [25], as well as in their key role as a recreational resource or tourist destination $[6,26]$. Some even looked into the educational purpose that natural areas might serve in an increasingly urban society [27]. All of these studies show that by the early 1980s the theoretical foundations for the utilization of natural areas were beginning to be laid. It was clear that, whether as a resource to safeguard environmental diversity or as a means to promote tourism, a correct planning could mean a profitable turnover.

This trend toward a mercantile view of protected natural areas underwent a qualitative evolution when the use of these areas for recreational purposes was combined with the need to make a sustainable use of them, which is in line with the research that had been done in other fields a decade earlier [28]. This resulted in a number of studies that specifically investigated aspects such as the carrying capacity of natural protected areas [29,30], while others delved into new phenomena that were brought about by the process of naturbanization [31,32] or into assessing their capacity to attract visitors [33].

Yet, despite the fact that research on natural spaces and protected areas is on the rise, few studies focus on tourist mobility-very often limiting themselves to a technical rather than tourist approach. In most cases, one can find publications that cover the use of advanced technology, such as radio telemetry, and its application to monitoring the spatial behavior of tourists in a given area [34]; the application of statistical analyses, such as Markov chains [35]. One can even find research based on the modelling of tourist flows [36] or on Probit models that estimate the number of visitors and their means of transportation [37].

Likewise, there exists research that specifically deals with mobility within the protected areas [38], as well as research that promotes innovative transportation solutions in order to create sustainable rural areas [39], or studies that investigate mobility from the point of view of governance and management models in the context of natural areas [40-42]. However, little by little, some new analyses have begun to emerge. These place the focus on mobility and the capacity to attract visitors as the key elements that facilitate the management of tourist destinations [43,44].

Despite all of this, the foregoing literature review-however concise-demonstrates that there is more than one way to look at mobility, although by and large, research on the subject does not focus on the capacity of protected areas to attract visitors, or on the place tourists start their journey from when they visit these areas, but rather on visitors' mobility inside the protected natural area. Thus, the present study complements the aforementioned approach to mobility, insofar as it assesses mobility before entering the natural area, which is an equally important aspect. Indeed, our data can be used in the policy-making process in order to highlight the centrality of protected areas as a resource, but also as the basis for customized tourist products that would improve customer experience, while also contributing towards sustainability in the process. In other words, for example, it would be possible to implement tourist itineraries that would rely on collective transportation instead of using private vehicles, which is the still the norm at present.

In view of the above, the need to assess the capacity of protected natural areas to attract visitors is thrown into relief. By the same token, it is also necessary to determine their area of influence. Both aspects are fundamental in order to promote a holistic governance of these areas, within a broader geographical context that is not circumscribed to the protected area itself. 


\section{Materials, Data and Method}

\subsection{The Case-Study}

According to the Consejería de Medio Ambiente y Rural, Políticas Agrarias y Territorio (the relevant branch of the regional government), the combined area of the protected areas in Extremadura is quite sizeable, as it covers $30.6 \%$ of a total $41,634 \mathrm{~km}^{2}$. This adds up to approximately 1,276,288.1 ha. Within this area, the Red Natura 2000 covers 1,257,787.05 ha. if we do not take into account the overlapping denominations in some areas. If the ZEPA areas (Areas of Special Conservational Purposes for Birds) and the LIC areas (Places of Importance for the Community) are considered separately, the former encompass 1,089,232.9 ha. and the latter 828,949.17 ha., respectively. It should be noted that all the LIC areas in Extremadura have been later designated as ZEC areas (Areas of Special Conservation), as published in the management plans of the Decreto 110/2015. This piece of legislation regulates the Ecological European Network Red Natura 2000 in Extremadura. However, Natural Protected Areas span 314,110.89 ha., largely overlapping with the Red Natura 2000. The list should also include the Monfragüe National Park, even though its size is subsumed in a ZEPA area-Monfragüe and surrounding Dehesa.

As can be surmised from the data above, there exists a rich natural heritage throughout most of the region. This heritage can be utilized as a tourist resource, especially for some types of tourism, such as certain niches with a specific demand, as is generally the case with ecotourism, or, more specifically, with birdwatching tourism.

Despite the scholarly and pragmatic interest that one may have in assessing the capacity of these protected areas to attract visitors, this study has selected just some of the most significant areas of this kind in order to measure their capacity to attract tourists, in an attempt to later to extrapolate those results. This is why our sample consists of a natural park, a national park, a natural reservation, and a natural monument.

\section{Study Area}

More specifically, the protected areas under analysis are the following: the Monfragüe National Park (Figure 2a), the Tajo Internacional Natural Park (Figure 2b), the Garganta de los Infiernos Natural Reservation, and the Los Barruecos Natural Monument. These are the pinnacle of tourist interest among their respective denominations according to the study by the Extremadura Observatory for Tourism [45]. This source indicates that in the year 2017, the Monfragüe National Park was the natural protected area that was chosen by most visitors among those staying in Extremadura-it was visited by $24.8 \%$ of them. One step below it we find the Garganta de los Infiernos Natural Reservation, which received $15.9 \%$ of visitors and, lagging a bit farther behind, we find the Los Barruecos Natural Monument and the Tajo Internacional Natural Park with $8.0 \%$ and $7.0 \%$ of visitors, respectively. Furthermore, all the rest of the protected areas combined only account for $13.1 \%$ of visitors [45].

It is only natural that the national park in the simple should be the most popular protected area, given the positive trend of visits to these areas, according to the data provided by the National Park Network. However, it should also be noted that the rest of natural areas receive a relatively low number of visitors. This is especially surprising when one takes into account the added value that they all have, such as being next to a World Heritage Site (the case of Los Barruecos); or, having a novel tourist product in Extremadura, a river cruise, that tours part of the Tajo Internacional Park; or the most emblematic swimming area in Extremadura, Garganta de los Infiernos, where peculiar granitic formations coexist with water.

These four areas, all of them clearly delineated, share a common characteristic besides their natural beauty: little demographic pressure, as corroborated by the data from the National Statistics Institute (INE) [46]. Indeed, according to the Municipal Register, the towns and villages within these areas are not densely populated (Table 1 ). 


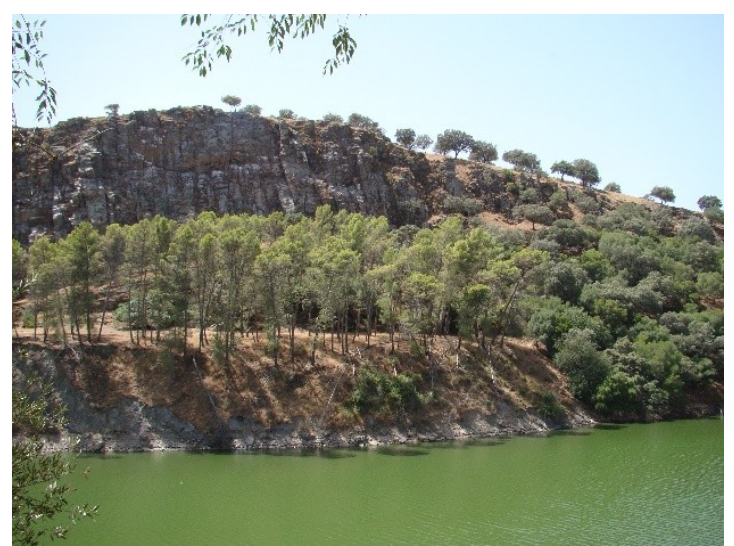

(a)

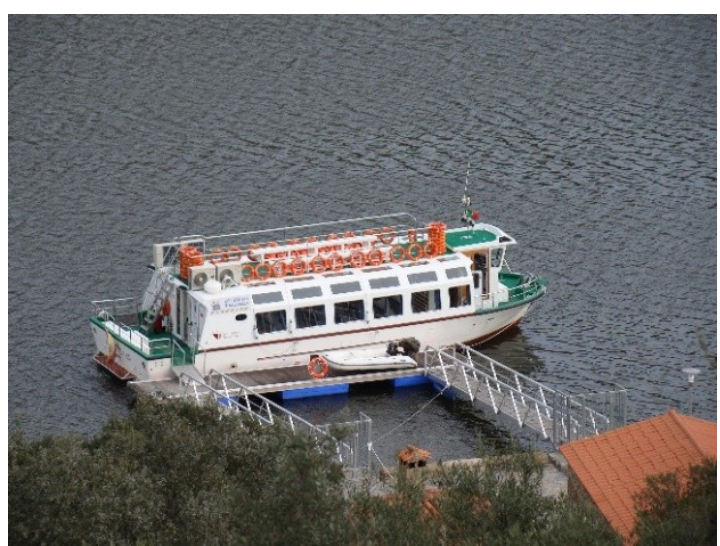

(b)

Figure 2. Resources and activities in the area of study: Monfragüe National Park (a) and Tajo International (b).

The analysis of the available accommodation shows that the level of tourist development is quite remarkable (Figure 3a), as the area tallies a 3511-person occupancy, which accounts for $8.5 \%$ of the whole tourist offer in Extremadura [47], albeit its distribution is rather unsystematic, both within each municipality and when regarding protected areas (Figure 3b) (Table 2). In addition, the above figures may be misleading, since $30.9 \%$ of the available offer is covered by tourist campsites and rural lodgings. In spite of this, the total volume of available accommodation remains notable, especially in certain towns in the National Park and the Natural Reservation, such as Malpartida de Plasencia and Jerte, respectively.

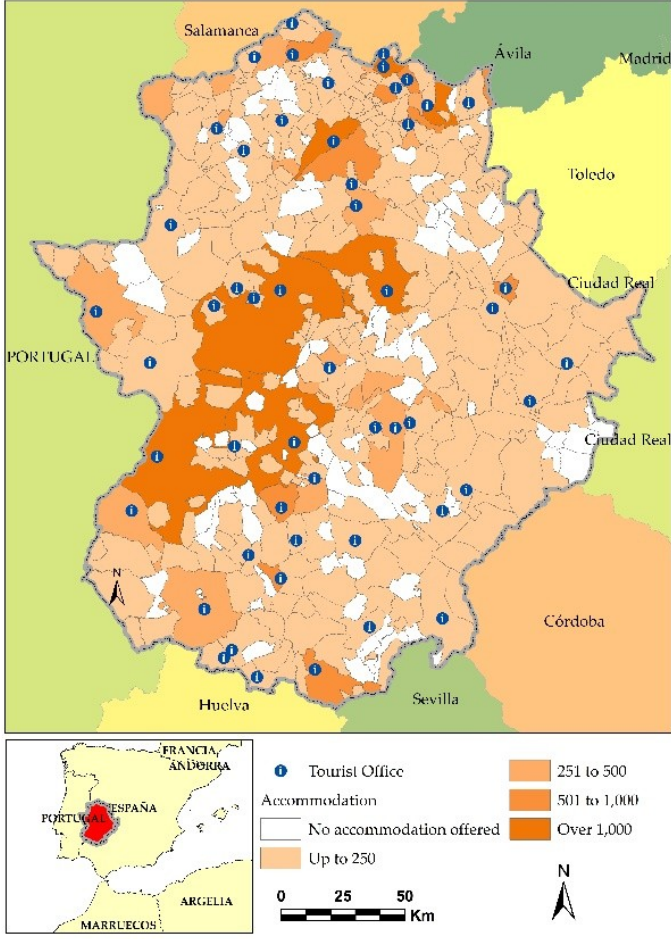

(a)

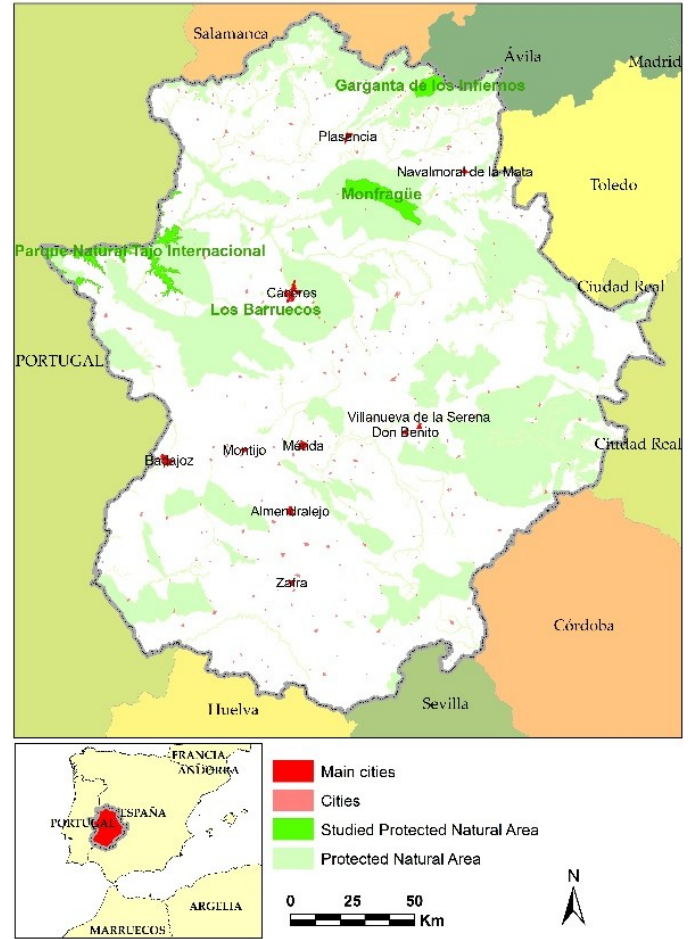

(b)

Figure 3. Available accommodation (a) and protected natural area (b).

Despite having a large number of accommodation businesses available, occupancy is usually poor. In fact, the Extremadura Observatory for Tourism, in their estimate for 2017, predicts an average 
occupancy of $16.1 \%$ for the vast territory of the north-west of the region, right where the Natural Reservation Garganta de los Infiernos is located; $19.5 \%$ for the Monfragüe National Park; and, $16.7 \%$ for both the area where the Tajo Internacional Natural Park lies and the Los Barruecos Natural Monument.

Table 1. Area of study.

\begin{tabular}{ccccc}
\hline Protected Natural Area & $\begin{array}{c}\text { Protected Area } \\
\text { (ha) }\end{array}$ & Municipalities & $\begin{array}{c}\text { Municipal Area } \\
\text { (ha) }\end{array}$ & $\begin{array}{c}\text { Population } \\
(\mathbf{2 0 1 7 )}\end{array}$ \\
\hline Monfragüe National Park & 18,396 & 7 & 135,642 & 8170 \\
Garganta Infiernos Natural Reserve & 6927 & 3 & 19,233 & 4737 \\
Los Barruecos Natural Monument & 319 & 1 & 3217 & 4268 \\
Tajo Internacional Natural Park & 25,088 & 11 & 250,155 & 13,591 \\
\hline
\end{tabular}

Source: National Statistics Institute (INE).

Table 2. Accommodation supply (available beds in 2017).

\begin{tabular}{|c|c|c|c|c|c|}
\hline Municipality & $\begin{array}{c}\text { Hotel } \\
\text { Accommodation } \\
\text { Places }\end{array}$ & $\begin{array}{c}\text { Rural } \\
\text { Accommodation } \\
\text { Places }\end{array}$ & $\begin{array}{c}\text { Non-hotel } \\
\text { Accommodation } \\
\text { Places }\end{array}$ & Total & $\%$ \\
\hline Casas de Miravete & 0 & 4 & 0 & 4 & $0.1 \%$ \\
\hline Jaraicejo & 23 & 12 & 0 & 35 & $1.0 \%$ \\
\hline Malpartida de Plasencia & 164 & 113 & 429 & 706 & $20.1 \%$ \\
\hline Serradilla & 0 & 74 & 0 & 74 & $2.1 \%$ \\
\hline Serrejón & 0 & 17 & 0 & 17 & $0.5 \%$ \\
\hline Toril & 0 & 43 & 16 & 59 & $1.7 \%$ \\
\hline Torrejón el Rubio & 170 & 160 & 0 & 330 & $9.4 \%$ \\
\hline SUM Monfragüe National Park & 357 & 423 & 445 & 1225 & $34.9 \%$ \\
\hline Cabezuela del Valle & 45 & 126 & 59 & 230 & $6.6 \%$ \\
\hline Jerte & 110 & 217 & 489 & 816 & $23.2 \%$ \\
\hline Tornavacas & 30 & 77 & 0 & 107 & $3.0 \%$ \\
\hline SUM Garganta Infiernos Natural Reserve & 185 & 420 & 548 & 1153 & $32.8 \%$ \\
\hline Alcántara & 118 & 50 & 0 & 168 & $4.8 \%$ \\
\hline Brozas & 98 & 10 & 6 & 114 & $3.2 \%$ \\
\hline Carbajo & 0 & 32 & 0 & 32 & $0.9 \%$ \\
\hline Cedillo & 0 & 10 & 52 & 62 & $1.8 \%$ \\
\hline Herrera de Alcántara & 0 & 49 & 0 & 49 & $1.4 \%$ \\
\hline Herreruela & 0 & 30 & 0 & 30 & $0.9 \%$ \\
\hline Membrío & 0 & 0 & 0 & 0 & $0.0 \%$ \\
\hline Salorino & 0 & 0 & 0 & 0 & $0.0 \%$ \\
\hline Santiago de Alcántara & 0 & 30 & 21 & 51 & $1.5 \%$ \\
\hline Valencia de Alcántara & 112 & 311 & 12 & 435 & $12.4 \%$ \\
\hline Zarza la Mayor & 0 & 48 & 0 & 48 & $1.4 \%$ \\
\hline SUM Tajo Internacional Natural Park & 328 & 570 & 91 & 989 & $28.2 \%$ \\
\hline Malpartida de Cáceres & 107 & 37 & 0 & 144 & $4.1 \%$ \\
\hline SUM Los Barruecos Natural Monument & 107 & 37 & 0 & 144 & $4.1 \%$ \\
\hline TOTAL SUM & 977 & 1450 & 0.1084 & 3511 & $100 \%$ \\
\hline PERCENTAGE & $27.8 \%$ & $41.3 \%$ & $30.9 \%$ & $100 \%$ & \\
\hline
\end{tabular}

Source: Extremadura Regional Government (Junta de Extremadura).

\subsection{Data}

The geodata that have been utilized in this study come from the National Topographic Database (scale: 1:100,000-BTN100) made available by the National Geographic Institute (Instituto Geográfico Nacional, or IGN) via their download center [48].

The geographical data that it contains provide thematic information at the aforementioned scale and they also have the right resolution for the purpose of this research; i.e., $20 \mathrm{~m}$. The database provides topographic data and thematic labels that serve as the basis for a number of processes that have been conducted with the aid of GIS software, among which one may mention spatial and alphanumeric queries, and, above all else, the network analysis that this research is based on, even though the software used here (Arc GIS v. 10.5) has many more capabilities. 
Alphanumeric data come from two main sources: the Registry of Tourist Businesses and the Extremadura Observatory for Tourism, both of which are integrated in the Dirección General de Turismo de la Junta de Extremadura, a sub-branch of the regional government. The Registry provided the information on the working accommodation businesses on 31 December, 2017. The most relevant data for our purposes was: the type and category of the business, the postal address, as well as the number of rooms and occupancy. Each of these places has been georeferenced and implemented on the GIS, together with the relevant information, so as to complement all other layers of information. The Observatory for Tourism, in turn, provided the information on the tourist demand for the whole year of 2017, consisting of a number of surveys filled by visitors to the region (Table 3). The survey records miscellaneous information about the profile of the visitor, their preferences, their opinions, the natural areas that they visited, the date, as well as the type of tourism they engage in. However, it must be noted that this study is based on the town visitors are staying in, which means only tourists are taken into consideration, not day-trippers and the like. All of this information has been implemented on the GIS, resulting in an ambitious project that has connected the centers at both ends of the tourist chain, while at the same time facilitating a disaggregated analysis of the demand in terms of the different tourist typologies.

Table 3. Technical data on the survey filled by tourists.

\begin{tabular}{|c|c|}
\hline Target Population & Tourists who Have Visited Extremadura in $2017(1,756,503)$ \\
\hline Size & 13,848 surveys \\
\hline Sampling & $\begin{array}{l}\text { Simple random sampling among the tourists who have visited one of the tourist information } \\
\text { offices in Extremadura and who have also stayed in one of the reference towns. }\end{array}$ \\
\hline Reliability & $95 \%$ \\
\hline Questionnaire & $\begin{array}{l}\text { Paper questionnaire filled in by the tourists who were offered to do so at one of the branches of } \\
\text { the Tourist Offices of Extremadura (Red de Oficinas de Turismo de Extremadura). The surveys } \\
\text { were later submitted via Google Docs by the staff of the Tourist Offices. }\end{array}$ \\
\hline Samping error & $\begin{array}{c}\text { For a reliability level of } 95 \% \text { and for the least favorable scenario }(p=q=0.50) \text {, the maximum } \\
\text { sampling error is } 1 \% .\end{array}$ \\
\hline Date & 1 January to 31 December 2017 \\
\hline
\end{tabular}

\subsection{Method of Analysis}

Two very different techniques have been used in order to facilitate the analysis. On the one hand, simple statistical calculations have been made in order to deal with alphanumeric data; and, on the other hand, a network analysis was deemed the most suitable method to find the fastest routes. The combination of these two techniques provides a rather good idea, albeit rough, of visitors' internal mobility towards the natural protected areas that are object of study here.

Regarding the statistical analysis of alphanumeric data-gathered from the aforementioned surveys channeled by the Observatorio Turístico de Extremadura-it is worthy of note that, given the main goal of this study (i.e., obtaining representative values), it was enough to construct a frequency distribution [49-51]. This straightforward technique, which is often used in other types of analysis, displays in a table all the information about the variables under scrutiny, and their corresponding frequency. SPSS v.19 software was used to obtain those frequencies.

This method allows to determine the percentage of tourists who visit each of the areas, or who intend to visit them during their stay, based on the information from the 52 tourist offices in Extremadura. These percentages have been categorized in terms of the yearly average and the type of tourism that visitors engage in. The frequency tables have been exported to an Excel spreadsheet in order for them to be implemented on ArcGIS.

The network analysis, in turn, yielded the minimum journey time between each tourist office and Villareal de San Carlos (in the Monfragüe National Park); Alcántara (the most popular town in the Tajo Internacional Natural Park); Cabezuela del Valle (the nearest town to the Garganta de los 
Infiernos Natural Reservation); and, Malpartida de Cáceres (nearest town to the Los Barruecos Natural Monument).

The speed limit for each road has been used in order to calculate impedance. However, given the lack of information in the cartography, the slower speed limits that are enforced in certain sections could not be factored in. Thus, motorways have been assigned a default speed of $120 \mathrm{~km} / \mathrm{h} ; 100 \mathrm{~km} / \mathrm{h}$ for national single carriageways; $90 \mathrm{~km} / \mathrm{h}$ for regional single carriageways; and, finally, $50 \mathrm{~km} / \mathrm{h}$ for local roads.

Given that it was not possible to assign more accurate speed values, calculations of the journey time were supplemented by data from journey planners, such as GoogleMaps and ViaMichelin—obtaining average negative deviations that range between $5 \%$ and $10 \%$. Sometimes, this margin of error is larger as a result of factors, such as the day of the week or the time at which the trip is planned. The journey planners yield the most accurate results, which is why the journey time assigned to each route is based on their data-once the fastest route was determined by means of the network analysis. This resulted in an approximate cartographic map of the most usual trips between the most popular tourist destinations and the natural areas under analysis. This defines the relevant isochrones from any given point in Extremadura.

\section{Description and Analysis of Results}

The results that were obtained from the analysis in this study can be divided into three main aspects. All of them have been acknowledged by those who are familiar with the tourist industry in Extremadura, although they had never been corroborated before-with the exception of the well-known differences between each of the areas when it comes to attracting visitors. The first aspect is the place of origin (i.e., the starting point of their journey and also the place they stay at) of the tourists who visit natural areas from the place they are staying at; the second one has to do with the average journey time for visitors in exploring the areas surrounding their place of stay; and, the third aspect is related to the geographical data of these journeys, which may contribute to maximizing the synergies between the visitors' final destination and the areas that they travel through in their journeys.

\subsection{Origin}

The natural areas under analysis receive visitors from many different places. However, when the internal mobility of visitors staying in Extremadura is analysed, their place of origin can usually be narrowed down to (and it overlaps, most often, with) the most popular towns in terms of the number of visitors-although other places within the 60-min isochrone are also significant.

In this regard, towns like Plasencia, Cáceres, Mérida, and Trujillo stand out as the nuclei that attract the most visitors among the four natural areas under study. Not for nothing do these towns concentrate the largest number of tourists and, consequently, it is more likely for them to make trips to the protected areas. In spite of this, it is also interesting to note that the presence of other consolidated destinations in the surrounding area is also a major factor in attracting visitors. Thus, towns like Jerte and Cabezuela del Valle attract visitors toward the Garganta de los Infiernos Natural Reservation - they are only a few minutes away from the parking area; the same applies to Alcántara and the Tajo Internacional Natural Park, etc. (Table 4).

Although the circumstances that are described here are largely general and they only apply to the areas in this study, certain specific characteristics may also be commented on. For example, towns that are quite far away, around 2-3 h, account for a surprisingly high number of visitors to the protected area, as in the case of Zafra or Badajoz, where between $2.6 \%$ and $3 \%$ of their tourists also visit the Monfragüe National Park. The same scenario can be seen in Guadalupe-around 140 min away from the Garganta de los Infiernos Natural Reservation-where 3.4\% of tourists staying there visit the reservation; or, from the same place to the Tajo Internacional Natural Park, which, despite being almost $3 \mathrm{~h}$ away, receives $3.1 \%$ of tourists staying in Guadalupe. These peculiarities are due to the rising popularity of the Monfragüe National Park, because it is the first area in Extremadura to have been 
awarded this status; but they also owe much to the appeal of the Garganta de los Infiernos Natural Reservation, where the geomorphology of the area results in the unusual granitic rock pools (usually known as "Pilones"). In addition, of course, the river cruise (an innovative tourist product) in the Tajo Internacional Natural Park can also be said to account for the aforementioned peculiarities.

Table 4. Place of origin of visitors to Natural Protected Areas in Extremadura.

\begin{tabular}{|c|c|c|c|c|c|c|c|}
\hline \multirow{11}{*}{ 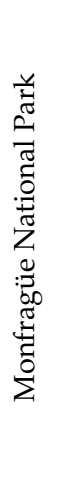 } & Overnight Stay & $\operatorname{Min} *$ & $\%$ PNA ** & \multirow{11}{*}{ 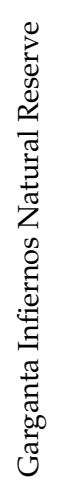 } & Overnight Stay & $\operatorname{Min} *$ & $\%$ PNA ** \\
\hline & Plasencia & 29 & 18.3 & & Plasencia & 36 & 18.4 \\
\hline & Cáceres & 70 & 18.2 & & Cáceres & 130 & 13.0 \\
\hline & Mérida & 115 & 11.8 & & Hervás & 49 & 12.6 \\
\hline & Trujillo & 56 & 8.1 & & Jerte & 8 & 7.8 \\
\hline & Hervás & 50 & 7.0 & & Mérida & 133 & 7.2 \\
\hline & Guadalupe & 117 & 3.5 & & Trujillo & 117 & 4.7 \\
\hline & Zafra & 150 & 3.0 & & Baños de Montemayor & 58 & 4.6 \\
\hline & Badajoz & 138 & 2.6 & & Jarandilla de la Vera & 85 & 4.3 \\
\hline & Jarandilla de la Vera & 82 & 2.6 & & Guadalupe & 140 & 3.4 \\
\hline & Jerte & 66 & 2.3 & & Cabezuela del Valle & 0 & 2.9 \\
\hline$\ddot{z}$ & Overnight Stay & Min * & $\%$ PNA ** & & Overnight Stay & $\operatorname{Min} *$ & $\%$ PNA ** \\
\hline छ & Cáceres & 19 & 24.3 & 苨 & Cáceres & 67 & 18.7 \\
\hline ప્ઞ & Plasencia & 59 & 12.7 & $\stackrel{0}{\circ}$ & Alcántara & 0 & 14.2 \\
\hline$\underline{\Xi}$ & Mérida & 55 & 11.5 & Z & Plasencia & 90 & 12.3 \\
\hline$\stackrel{\pi}{3}$ & Trujillo & 51 & 6.7 & ฮี & Mérida & 104 & 11.4 \\
\hline 茔 & Hervás & 77 & 6.3 & ?.0 & Trujillo & 99 & 5.6 \\
\hline o & Badajoz & 84 & 4.2 & $\tilde{\Xi}$ & Hervás & 107 & 3.8 \\
\hline$\underset{\Xi}{Z}$ & Guadalupe & 129 & 3.7 & $\stackrel{\Xi}{\Xi}$ & Villafranca de los Barros & 123 & 3.7 \\
\hline Фี & Zafra & 88 & 3.0 & $\frac{0}{\pi}$ & Valencia de Alcántara & 52 & 3.6 \\
\hline 8 & Jarandilla de la Vera & 115 & 3.0 & & Guadalupe & 177 & 3.1 \\
\hline & Villanueva de la Serena & 90 & 2.6 & & Badajoz & 126 & 2.8 \\
\hline
\end{tabular}

${ }^{*}$ Travelling time (minutes), ${ }^{* *}$ Protected Natural Area (\% of visitors).

\subsection{Journey Time as an Argument}

When one analyzes the number of tourists that come from the different places they are staying in, it is then possible to ascertain the capacity to attract visitors of each of the natural areas (Figure 4). In this regard, the number of tourists staying in a specific town is no longer the main factor, but rather the trips they make from their place of stay. Therefore, if one wishes to analyze the capacity that natural areas have in order to attract visitors, it is necessary to emphasize the share of tourists who visit them from the place that they are staying in. In this case, the 41 towns and villages with the largest number of visitors have been considered, according to the surveys managed by the Observatory for Tourism.

These data reveal that visitors' internal mobility from the place of stay toward protected areas show a common pattern: the longer the journey trip, the fewer the visitors. This pattern is particularly evident when the journey time is over one hour-one-way trip, not return, is considered. A clear manifestation of this can be observed in the case of the Monfragüe National Park. Despite its incredible potential to attract visitors, the percentage of tourists decreases considerably when the journey time reaches $60 \mathrm{~min}$, and the drop is even sharper when it goes over the 90-min isochrone. Something similar happens in the rest of natural areas that are studied here, which leads to the conclusion that tourists who may visit them lose interest as the distance increases. At the same time, it should again be mentioned that the capacity to attract visitors in these areas varies considerably. Furthermore, there exist a significant percentage of visitors who go over the 1-h journey time, because they make a stop to visit the natural areas in route to/from their places of stay. 
This behavior is noticeable in the four areas object of study, although it is much more significant in those areas with the most visitors, as upward of $50 \%$ of tourists travel to these areas. This establishes a series of correlated journeys when comparing the journey times and the percentage of visitors.
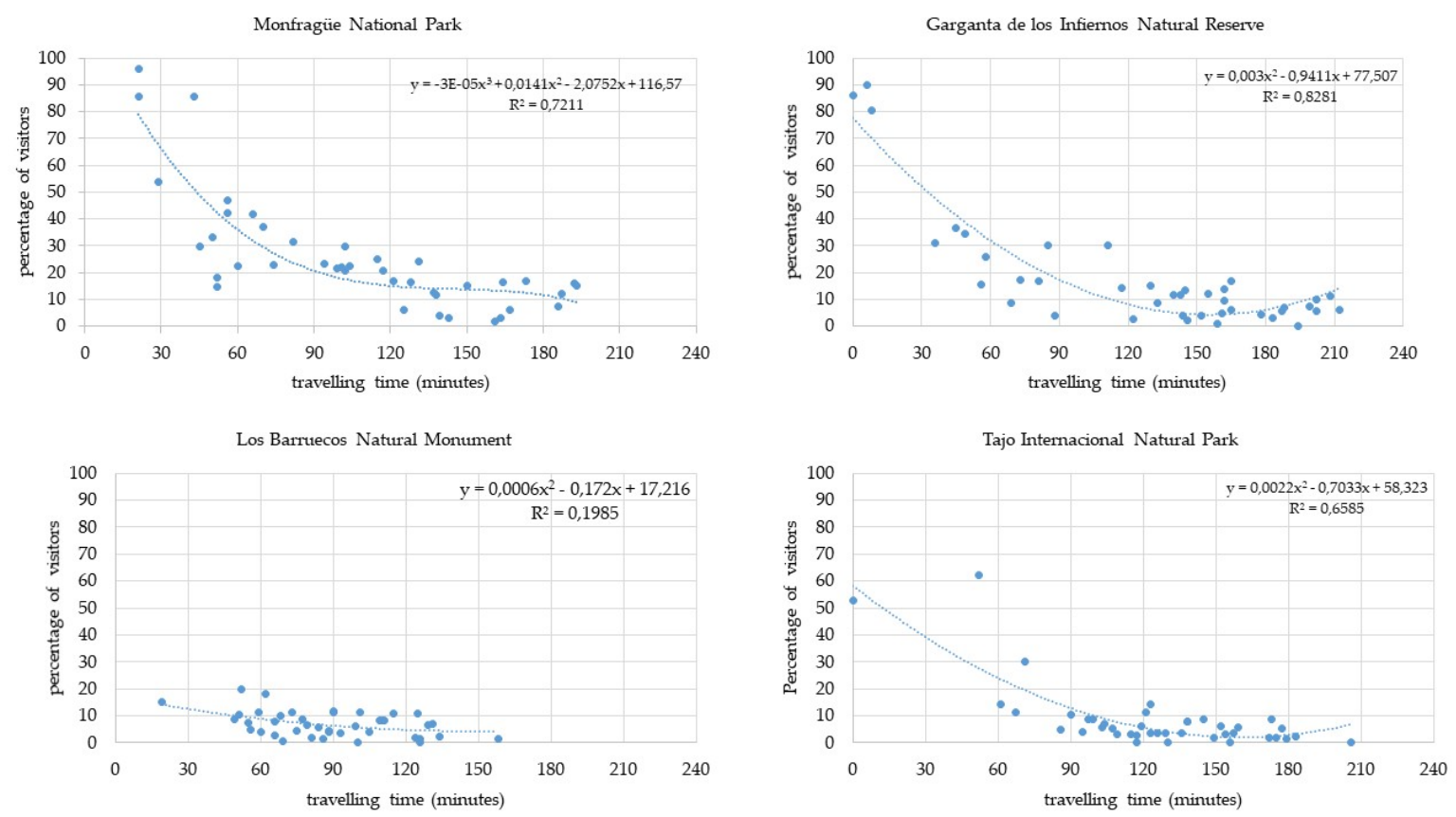

Figure 4. Journey times from the places of stay to the Natural Protected Areas.

\subsection{Most Popular Routes}

Given the importance of the flow of visitors from their place of stay to the protected areas, it seems necessary to analyze in detail each of the former, as the scenario varies a great deal depending on the place under study. Yet, in spite of the available information on the 41 towns in Extremadura with the largest number of tourists, this study will focus solely on the 15 towns that the most visitors to natural areas come from.

\subsubsection{Monfragüe National Park}

The Monfragüe National Park has a remarkable capacity to attract visitors, although it intensifies, in particular, in the towns of the surrounding area, such as Torrejón el Rubio, Malpartida de Plasencia, and Serradilla. In the case of these three towns, part of whose geographical limits overlap with the protected area, the number of tourists who visit the park exceeds $85 \%$. Still, significant figures also appear in places as far away as Valencia de Alcántara and Mérida-around 131 and 115 min away, respectively, from Villareal de San Carlos, in the heart of the park. (Table 5) This suggests that Monfragüe is a major tourist hub for tourists who have stayed/are staying in most of Extremadura. Indeed, there are places, like Fregenal de la Sierra, around $3 \mathrm{~h}$ away from the park, where over $7 \%$ of tourists visit Monfragüe. This considerable distance is a clear indication that visitors use their journey to their place of stay or their homes in order to visit the park-a circumstance that is facilitated by the proximity of high-capacity roads, such as the A-66 highway.

\subsubsection{Garganta de los Infiernos Natural Reservation}

A high percentage of tourists who stay in nearby towns visit this protected area. In fact, more than $80 \%$ of tourists staying in places like Navaconcejo, Cabezuella del Valle or Jerte visit this protected area (Table 6). However, as the journey time grows, the percentage of visitors decreases sharply-even though Garganta de los Infiernos still attracts tourists from towns as far away as Cáceres and Trujillo, which lie around the 2-h journey time. 
Table 5. Percentage of tourists who visit the Monfragüe National Park from their place of stay.

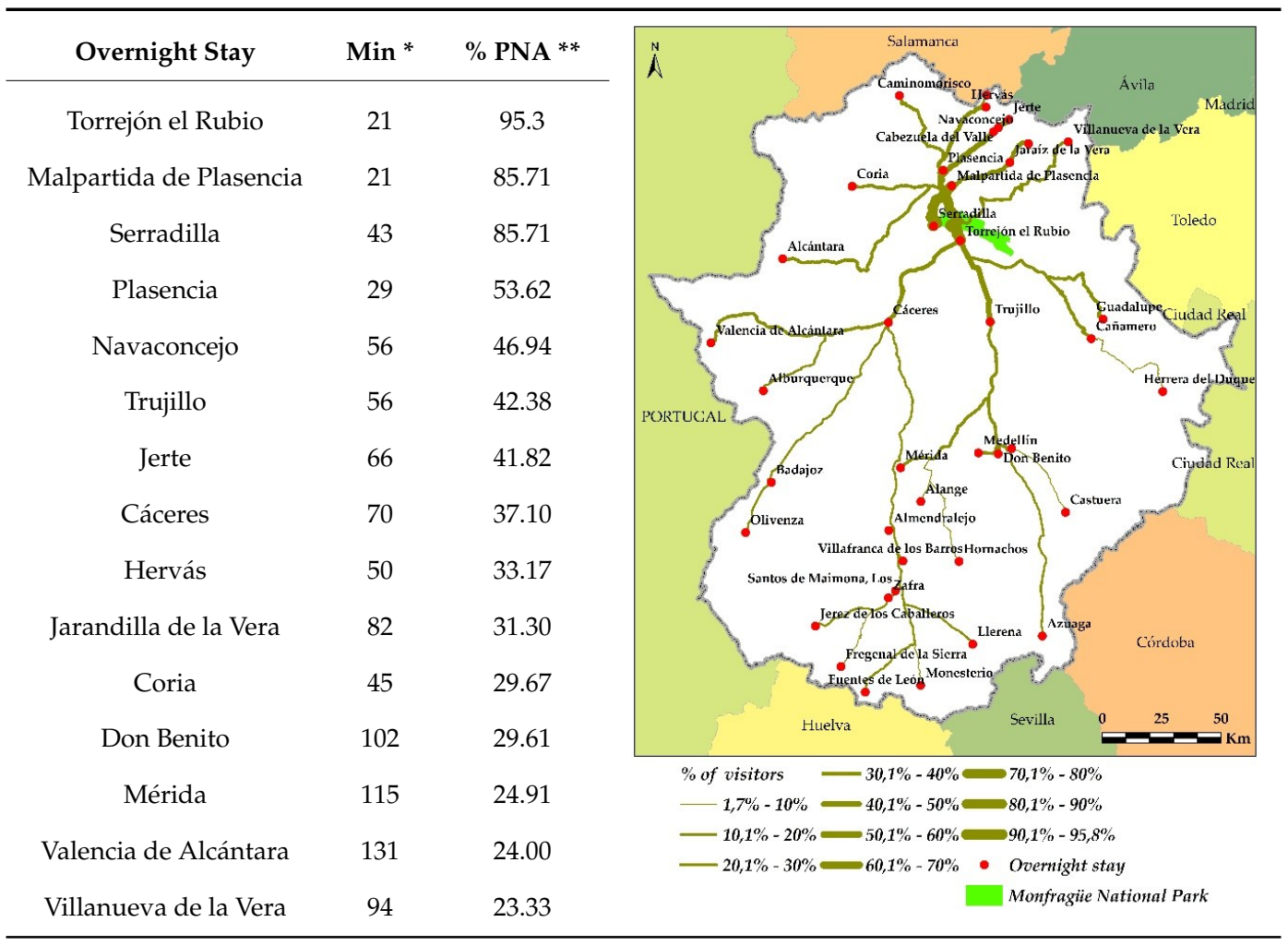

* Travelling time (minutes), ${ }^{* *}$ Protected Natural Area (\% of visitors).

Table 6. Percentage of tourists who visit the Garganta de los Infiernos Natural Reservation from their place of stay.

\begin{tabular}{|c|c|c|c|}
\hline Overnight Stay & $\operatorname{Min} *$ & $\%$ PNA ** & ancal \\
\hline Navaconcejo & 6 & 89.80 & \\
\hline Cabezuela del Valle & 0 & 86.21 & \\
\hline Jerte & 8 & 80.61 & Toledo \\
\hline Malpartida de Plasencia & 45 & 36.51 & \\
\hline Hervás & 49 & 34.29 & \\
\hline Plasencia & 36 & 31.12 & \\
\hline Jarandilla de la Vera & 85 & 30.08 & ORT \\
\hline Villanueva de la Vera & 111 & 30.00 & \\
\hline Baños de Montemayor & 58 & 25.83 & \\
\hline Serradilla & 73 & 17.14 & \\
\hline Torrejón el Rubio & 81 & 16.67 & \\
\hline Medellín & 165 & 16.67 & \\
\hline Jaraíz de la Vera & 56 & 15.67 & ${ }^{50} \mathrm{Km}$ \\
\hline Cáceres & 130 & 15.21 & $\%$ of visitors $-40,1 \%-50 \% \quad$ Garganta de los Infiernos Nat. Res. \\
\hline Trujillo & 117 & \multirow[t]{2}{*}{14.18} & $\begin{array}{l}-0 \%-10 \% \underset{-50,1 \%-60 \%}{-} \quad \cdot \text { Overnight stay } \\
-10,1 \%-20 \%=60,1 \%-70 \%\end{array}$ \\
\hline \multicolumn{2}{|c|}{ * Travelling time (minutes) } & & $-20,1 \%-30 \%=70,1 \%-80 \%$ \\
\hline ** Protected Natural & rea $(\%$ o & isitors) & $-30,1 \%-40 \% \Longrightarrow 80,1 \%-89,8 \%$ \\
\hline
\end{tabular}




\subsubsection{Los Barruecos Natural Monument}

Its capacity to attract visitors from the surrounding area is rather limited, since, even in the best cases, it barely attracts $20 \%$ of tourists staying in the nearby area (Table 7). In this case, the towns of Alburquerque, Valencia de Alcántara y Cáceres have been shown to produce the largest share of tourists toward this protected area. This is largely due to two main reasons: it lies on the route to the first two towns mentioned before and it is very close to Cáceres. Still, it can be observed that the percentage of visitors decreases steadily as the journey time increases.

Table 7. Percentage of tourists who visit the Los Barruecos Natural Monument from their place of stay.

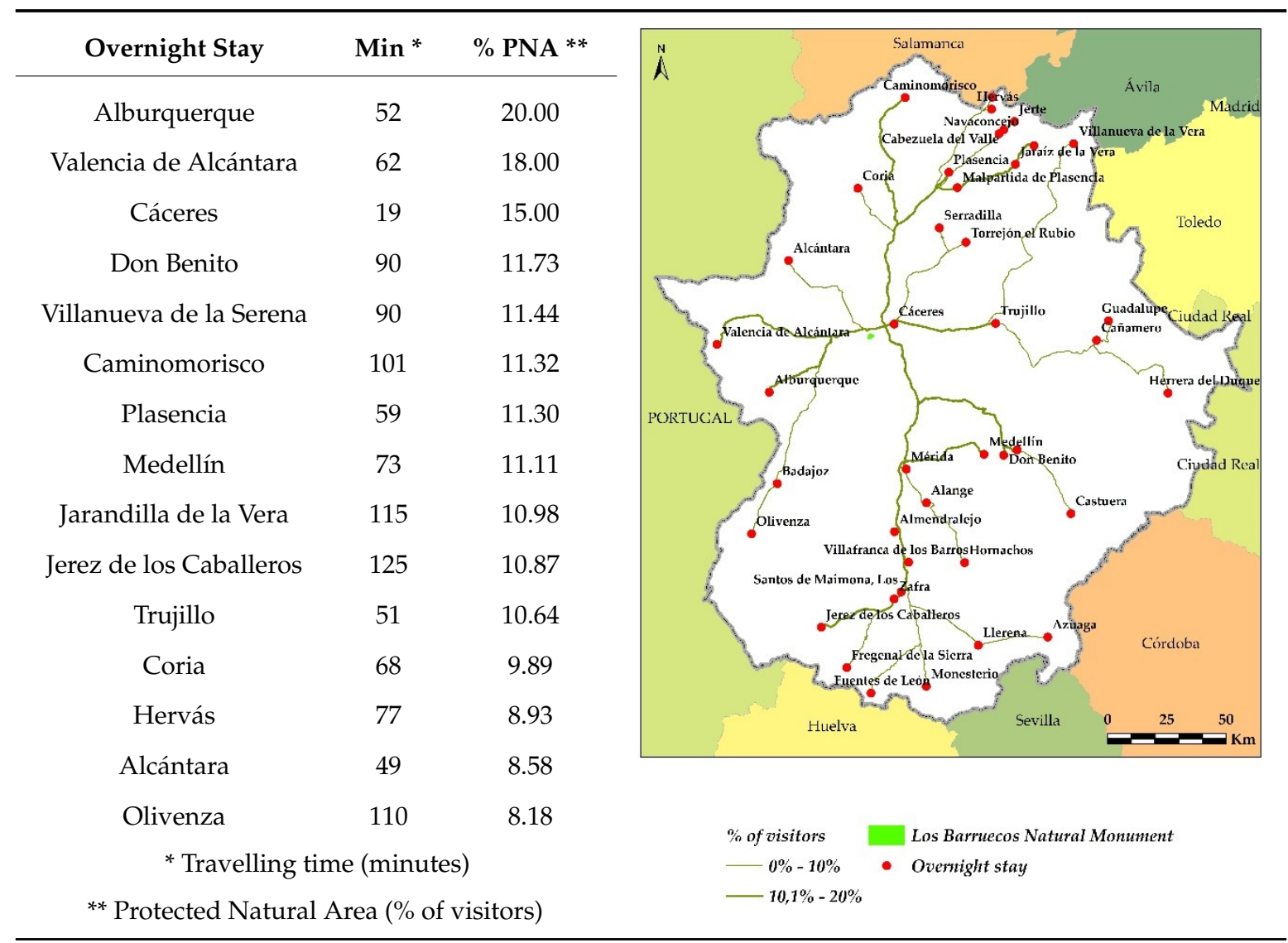

\subsubsection{The Tajo Internacional Natural Park}

The capacity that this area has to attract visitors is also closely connected to the criterion of proximity (Table 8). In order to determine this capacity, this study used Alcántara as a reference (one of the most popular tourist towns, which is also close to the park). In this regard, it should be noted that tourists staying in places like Valencia de Alcántara and Alcántara, less than an hour away, are the keenest to know the Tajo Internacional area, as between $62 \%$ and $52 \%$ of them visit the park.

Despite this, it can be observed that, once beyond the 1-h isochrone, the capacity to attract visitors decreases very noticeably. This is due to the geographical location of the area within Extremadura, as it lies on its periphery. Nevertheless, relatively distant visits can also be found, which are largely motivated by the presence of a tourist product that has consolidated over the years (river tourism) thanks to the presence of a river cruise, which also relays tourists towards other destinations in Portugal, which are also attractive to visitors. 
Table 8. Percentage of tourists who visit the Tajo Internacional Natural Park from their place of stay.

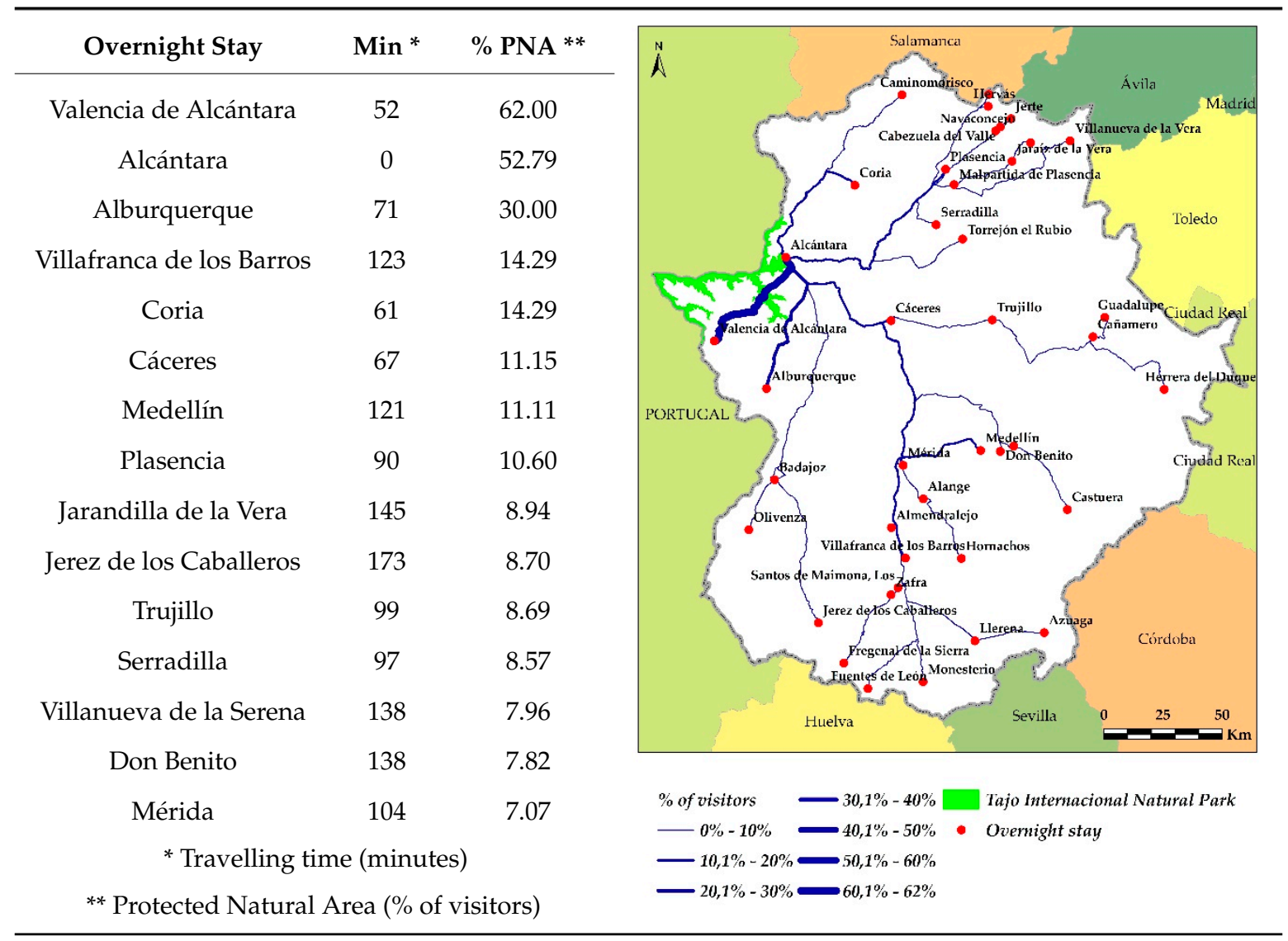

\section{Discussion and Evaluation of Results}

In the relevant literature, there exists a growing interest in knowing the flow of tourists once they are at their destination, although this analysis can be addressed from different perspectives, such as that of economics or geography, among others [35]. These studies usually focus on the mobility within the destination, considered as a tourist space of its own-usually at a local scale, as in specific cities [52,53], but also in a wider area [54] or even on a global scale [55]. Despite the abundant literature on the measuring of tourist flows, there are very few publications on our area of study (Extremadura), and especially so in the case of protected natural areas. This is why the findings of this study are of special significance, as they provide a holistic overview of three specific aspects.

First of all, it can be observed how the role of natural protected areas in the tourist industry has been on the rise, especially if one looks into the most important denomination, the National Park. In this specific regard, there are a number of studies that deal with different aspects of tourism, such as the demand [56], specific products, such as birdwatching tourism [57], and even the tourist resources that it has [58]. However, none of the publications that have been consulted looks into the capacity of protected areas to attract visitors from the main tourist destinations in the region.

Second, it is clear that the range of tourists, and, by parallel, the number of tourists who stay at a destination, shape the origin of visitors in any of the areas under scrutiny. This aspect is of special relevance, because it delves into their mobility at the destination, as opposed to simply considering their province of origin, which may conceal the data on the true mobility at the destination.

Third, this study shows the key role that is played by the journey time from the place of stay to the protected areas-with an obvious decrease in visitors as the isochrone grows, that as in other domain $[43,44]$.

The three aspects that have just been mentioned constitute the main findings of the present study. They can be used in order to manage the utilization of the natural protected areas more efficiently, 
at least as far as their role as tourist resources is concerned. After all, the very term "natural protected area" implies that they will serve as environmental resources, but also that they may be used for recreational purposes as long as this is done with sustainability in mind. In this regard, it must be noted that the concept of sustainability, when applied to these areas, should go above and beyond the preservation of the ecosystem, for it is also necessary to achieve social sustainability, in order to keep the human population in these natural sites and the surrounding area. This, in turn, can only be achieved through economic gain, which will also ensure, or, at least, facilitate, economic sustainability.

It is therefore understood that the survival and the very raison d'être of natural protected areas depends on the balance between the three basic pillars of sustainability: environment, society, and economy. Perhaps the economy is the most important of the three for this research, because if there is no money to be made from protected areas, the human population is likely to dwindle, and, as a result, the environment may also suffer, especially if environmental protection is seen as an impediment to economic development.

In light of the above, we believe that the results of this study can lead to the implementation of policies conducive to the economic development of said areas, where tourism has to play a major part. This means that it is necessary to design a strategic plan that specifically targets sustainable development in these areas, while at the same time preventing the negative impacts of mass tourism. Unfortunately, the consequences of mass tourism can already be seen around some of the landmarks of the areas analyzed here, such as the Salto del Gitano at Monfragüe National Park or the popular swimming area of Los Pilones, inside the Garganta de los Infiernos Natural Reservation.

Regardless of the fact that this planning process necessarily implies much additional work besides this article, there is no gainsaying the fact that gauging the capacity to attract visitors that these areas have is a valid starting point. Thus, it allows us to know the areas where the most visitors come from as well as their most usual routes when they travel from their places of stay to the natural areas. These data, interesting in their own right for marketing campaigns, must be integrated into the design of customized tourist products that make it possible to monitor visitors to a certain extent, but also to offer customized guided tours that begin at their places of stay.

Therefore, the results herein can guide all of the institutions responsible for managing these areas toward the ideal target towns for their advertising campaigns. In addition, our data allows them to design tourist itineraries where collective transportation with tourist guides can be provided. This would represent a twofold advantage. On the one hand, fewer private vehicles would be used in these areas. On the other, the tourist experience would be enhanced by the availability of specialized tourist guides. Furthermore, there are a couple of issues that the administrations in charge of managing these areas should be made aware of. First, they should not simply promote the present state of affairs, where the overwhelming majority of visitors are hikers and day-trippers, but rather encourage tourism, which would yield greater economic benefits because it would be a boost to accommodation businesses, and, needless to say, it would create jobs. This, as a consequence, would give the rural population a reason to stay.

\section{Conclusions}

The main conclusions that can be drawn from this study are directly linked to the goals that we established at the outset. First, it was demonstrated that the natural protected areas in Extremadura that were chosen for this piece of research had varying capacities to attract visitors. In this regard, the Monfragüe National Park stands out at the top of the list. In addition, it should be noted that each natural area has a differentiated attraction area. These areas area shaped, depending on the case, by the proximity of the places of stay or the tourist significance of the places of origin.

Therefore, a synthetic conclusion may be outlined, as follows:

First of all, tourist mobility at the destination (among those who choose to visit the most popular protected natural areas in Extremadura) pivots around the Monfragüe National Park and the Garganta de los Infiernos Natural Reservation, whereas the Tajo Internacional Natural Park and the Los Barruecos 
Natural Monument lag behind considerably. This suggests that the legal status of each protected area influences the number of visitors, and consequently, the tourist flow.

Second, the number of visitors to each of the protected areas positively correlates with the tourist significance of their place of stay, so that consolidated destinations, such as Cáceres, Mérida, Trujillo, and Plasencia, provide a large number of day-trippers to these natural areas.

Third, the capacity to attract visitors of each of the areas object of study is circumscribed within the 60-min isochrone for one-way trips. However, there are notable differences among the protected areas, which depend mostly on the type of protected area they are (legal status). In this regard, the Monfragüe National Park leads the rank because it attracts visitors from the greatest distances.

Finally, it should also be noted that tourists tend to use their trips from their homes to their places of stay in order to visit the nearest protected areas in route.

On a related note, this research will be shortly complemented by the combined analysis of the tourists' mobility towards those protected areas and their socioeconomic characteristics. The resulting data will surely facilitate the tuning of specific products in order to cater for different segments of the population.

Despite the applicability of this study, its main limitation lies in the assumption that visitors take the fastest route-although reliability tests indicate that $95 \%$ of visitors indeed choose the fastest route. In addition, tourists who visit Extremadura but do not stay overnight have not been considered here.

Author Contributions: Conceptualization, J.M.S.S. and J.I.R.G.; methodology, J.M.S.M. and J.I.R.G.; formal analysis, J.M.S.M.; J.I.R.G. and L.M.M.D.; investigation, J.M.S.M.; resources, J.I.R.G.; data curation, L.M.M.D.; Writing-Original Draft preparation, J.M.S.M. and J.I.R.G..; Writing-Review and Editing, J.M.S.M. and J.I.R.G.; supervision, J.M.S.M.; project administration, J.M.SM..; funding acquisition, J.M.S.M.

Funding: This publication is part of the research carried out within the research project "Diseño y elaboración de productos estratégicos diferenciados para la potenciación del turismo rural en Extremadura. De la detección de problemas a la propuesta de soluciones basadas en criterios geoestadísticos" (Code IB 16040). This Project is funded by the Consejería de Economía e Infraestructuras de la Junta de Extremadura (the branch of the regional government that covers economy and infrastructure) and by the European Regional Development Fund (ERDF).

Conflicts of Interest: The authors declare no conflict of interest. The funders had no role in the design of the study; in the collection, analyses, or interpretation of data; in the writing of the manuscript; or in the decision to publish the results.

\section{References}

1. Ortuño, F. Visión panorámica, a nivel mundial, de las políticas de espacios protegidos. In Planificación y Gestión de Espacios Naturales Protegidos; Viedma, G., Ortuño, F., Fernández, J., Aboal, J., Eds.; Fundación Conde del Valle de Salazar: Madrid, Spain, 1982; pp. 1-22. ISBN 84-300-7176-8.

2. Soler, J. Los espacios naturales. In Manual de Ciencia del Paisaje; Masson: Barcelona, Spain, 1992; p. 288, ISBN 978-84-311-0595-2.

3. Flores Ruiz, D. Competitividad Sostenible de los Espacios Naturales Protegidos como Desttinos Turísticos: Un Análisis Comparativo de los Parques Naturales Sierra de Aracena y Picos de Aroche y Sierras de Cazorla, Segura y Las Villas (Tesis Doctoral); Universidad de Huelva: Huelva, Spain, 2007; 628p, ISBN 978-84-691-8955-9.

4. Tolón Becerra, A.; Lastra Bravo, X. Los espacios naturales protegidos. Concepto, evolución y situación actual en España. Revista Electrónica de Medioambiente 2008, 5, 1-25.

5. Vacas Guerrero, T. Los espacios naturales protegidos como recurso turístico. Metodología para el estudio del Parque Nacional de Sierra Nevada. Estudios Turísticos 2001, 147, 57-84.

6. Garayo Urruela, J. Los espacios naturales protegidos: Entre la conservación y el desarrollo. Lurralde: Investigación y Espacio 2001, 24, 271-293.

7. González, F. Relación Entre Espacios Naturales Protegidos y Protegibles: Los Términos de una Polémica. Coloquio Hispano-Francés Sobre Espacios Naturales; Casa de Velázquez: Madrid, Spain, 1988; pp. 45-62, ISBN 84-7479-775-6.

8. MAPAMA. Available online: https:/ / www.mapa.gob.es/es/ (accessed on 15 May 2018).

9. Antón Clavé, S. Medioambiente y política turística. Estudios Turísticos 1992, 116, 5-25.

10. Vacas Guerrero, T. Patrimonio natural: Uso público-turistico en los espacios naturales protegidos españoles. Estudios Turísticos 2010, 186, 69-91. 
11. Ruzza, C. Environmental Sustainability and Policy Networks in Tourist Locations. Policies, Governance and Innovation for Rural Areas; Universidad de Calabria: Arcavacata, Italy, 2003; pp. 1-22.

12. Torres Delgado, A.; López Palomeque, F. The growth and spread of the concept of sustainable tourism: The contribution of institutional initiatives to tourism policy. Tour. Manag. Perspect. 2012, 4, 1-10. [CrossRef]

13. Baral, N.; Hazen, H.; Thapa, B. Visitor perceptions of World Heritage value at Sagarmatha (Mt. Everest) National Park, Nepal. J. Sustain. Tour. 2017, 24, 1494-1512. [CrossRef]

14. Kruger, M.; Viljoen, A.; Saayman, M. Who visits the Kruger National Park, and why? identifying target markets. J. Travel Tour. Mark. 2017, 34, 312-340. [CrossRef]

15. Sabuhoro, E.; Wrigth, B.; Munanura, I.; Nyakabwa, I.; Nibigira, C. The potential of ecotourism opportunities to generate support for mountain gorilla conservation among local communities neighboring Volcanoes National Park in Rwanda. J. Ecotour. 2017. [CrossRef]

16. Espejo, R. The soils and ages of the "raña" surfaces related to the Villuercas and Altamira mountain ranges (Western Spain). CATENA 1987, 14, 399-418. [CrossRef]

17. Espejo, R. Evolución geomorfológica y procesos erosivos en las formaciones de reaña relacionadas con las sierras de las Villuercas y Altamira (W de España). Ecología 1988, 2, 39-51.

18. Sánchez Martín, J.M.; Rengifo Gallego, J.I. Los espacios naturales protegidos y su capacidad de atracción turística: Referencias al Parque Nacional de Monfragüe (Extremadura-España). In Intellectual Capital and Regional Development: New Landscapes and Challenges for Planning the Space; APDR: Covilhâ, Portugal, 2017; pp. 1196-1206. ISBN 978-989-8780-05-8.

19. National Parks Network. Available online: https://www.miteco.gob.es (accessed on 30 September 2018).

20. Garzón García, R.; Ramírez López, M. Las áres protegidas como territorios turísticos: Análisis crítico a partir del caso de los parques naturales de la Sierra Morena andaluza. Cuadernos de Turismo 2018, 41, $249-277$.

21. Antón Clavé, S.; Blay Boqué, J.; Salvat Salvat, J. Turismo, actividades recretivas y uso público en los parques naturales. Propuesta para la conservación de los valores naturales ambientales y el desarrollo productivo local. Boletín de la Asociación de Geógrafos Españoles 2008, 48, 5-38.

22. Pulido Fernández, J.I. Criterios para una Política Turística Sostenible en los Parques Naturales de Andalucía; Junta de Andalucía, Consejería de Turismo, Comercio y Deporte: Seville, Spain, 2005; 839p, ISBN 978-84-689-4764-4.

23. Pulido Fernández, J.I. Elementos para orientar la formulación de una política turística sostenible en los parques naturales andaluces. Cuadernos de Turismo 2007, 19, 167-188.

24. Valenzuela Rubio, M. El uso recreativo de los espacios naturales de calidad. (Una reflexión sobre el caso español). Estudios Turísticos 1984, 82, 3-14.

25. Garay Zabala, J. Planificación de la interpretación y visitas en los espacios naturales protegidos. In Planificación y Gestión de Espacios Naturales Protegidos; Fundación Conde del Valle de Salazar: Madrid, Spain, 1982; pp. 301-324. ISBN 84-300-7176-8.

26. Aboal, J. Aspectos turístico-recreativos de los espacios naturales. In Planificación y Gestión de Espacios Naturales Protegidos; Fundación Conde del Valle de Salazar: Madrid, Spain, 1982; pp. 153-186. ISBN 84-300-7176-8.

27. Ruiz-Dana, J. Aspectos educacionales de los espacios naturales. In Planificación y Gestión de Espacios Naturales Protegidos; Fundación Conde del Valle de Salazar: Madrid, Spain, 1982; pp. 129-152. ISBN 84-300-7176-8.

28. Clark, J. Carrying capacity: The limits to tourism. In Proceedings of the Congress on Marine Tourism, East/West Conference Center, Honolulu, HI, USA, 25-31 May 1990.

29. Roig i Munar, F. Análisis de capacidad de carga en los espacios litorales, calas y playas situados en áreas naturales de especial interés de la isla de Menorca. In Turismo y transformaciones urbanas en el siglo XXI; Universidad de Almería: Almería, Spain, 2002; pp. 327-355. ISBN 84-8240-521-7.

30. Viñals, M.; Planelles, M. La capacidad de carga recreativa en pequeñas islas del Mediterráneo. Cuadernos de Turismo 2016, 37, 547-553.

31. Prados Velasco, M.J.; del Valle Ramos, C. Naturbanización y cambios en la población de los espacios naturales de Doñana y Sierra Nevada. Documents D'anàlisi Geogràfica 2010, 56, 435-460.

32. Tulla Pujol, A.; Vera Martín, A.; Badia Perpinyá, A.; Pallarés Barberá, M. Actividades económicas y naturbanización en el entorno de los parques naturales del "Cadí-Moixeró" y del "Alt Pirineu“ (Pirinero Catalán). In Proceedings of the III Coloquio Hispano-Francés de Geografía Rural, Baeza, Spain, 28-30 May 2007; pp. 93-116, ISBN 978-84-691-1464-3.

33. Prados Velasco, M.J. Los parques naturales como factor de atracción de la población. Un estudio exploratorio sobre el fenómeno de la naturbanización en Andalucía. Cuadernos Geográficos 2006, 38, 87-110. 
34. Fenell, D. A tourist space-time budget in the Shetland Islands. Ann. Tour. Res. 1996, 23, 811-829. [CrossRef]

35. Xia, J.; Zeepphongsekul, P.; Packer, D. Spatial and temporal modelling of tourist movements using Semi-Markov processes. Tour. Manag. 2011, 32, 844-851. [CrossRef]

36. Yang, Y.; Fik, T.; Zhang, J. Modeling sequential tourist flows: Where is the next destination? Ann. Tour. Res. 2013, 43, 297-320. [CrossRef]

37. Masiero, L.; Zoltan, J. Tourists intra-destination visits and traansport mode: A bivariate probit model. Ann. Tour. Res. 2013, 43, 529-546. [CrossRef]

38. López Lambas, M.; Ricci, S. Planning and management of mobility in natural protected areas. In Proceedings of the XVIII Congreso Panamericano de Ingeniería de Tránsito, Transporte y Logística (PANAM 2014), Santander, UK, 11-13 June 2014; pp. 320-329, ISBN 978-84-617-0085-1. Available online: https:/ /www. sciencedirect.com/science/article/pii/S1877042814063149 (accessed on 15 June 2018).

39. López-Iglesias, E.; Peón, D.; Rodríguez-Álvarez, J. Mobility innovations for sustainability and cohesion of rural areas: A transport model and public investment analysis for Valdeorras (Galicia, Spain). J. Clean. Prod. 2018, 172, 3520-3534. [CrossRef]

40. Eagles, P. Governance of recreation and tourism partnerships in parks and protected areas. J. Sustain. Tour. 2009, 17, 231-248. [CrossRef]

41. Lockwood, M. Good governance for terrestrial protected areas: A framework, principles and performance outcomes. J. Environ. Manag. 2010, 91, 754-766. [CrossRef] [PubMed]

42. Romagosa, F.; Eagles, P.F.J.; Buteau Duitschaever, W. Evaluación de la gobernanza en los espacios naturales protegidos. El caso de la Columbia Británica y Ontario (Canadá). Anales de Geografía de la Universidad Complutense 2012, 32, 133-151. [CrossRef]

43. Sánchez Martín, J.M.; Rengifo Gallego, J.I.; Martín Delgado, L.M. El diseño de itinerarios culturales en Extremadura y la localización de los bienes inscritos en el Patrimonio Mundial de la Unesco. In Proceedings of the XII International Conference of Tourism and Information \& Communication Technologies, Málaga, Spain, 10-11 October 2018; pp. 281-296, ISBN 978-84-09-05554-8. Available online: http:/ / turitec.com/wpcontent/uploads/2018/10/TURITEC-2018-proceedings.pdf (accessed on 15 October 2018).

44. Sánchez Martín, J.M.; Rengifo Gallego, J.I.; Martín Delgado, L.M. La ciudad de Cáceres como centro difusor de turistas hacia el entorno rural. In Proceedings of the XII International Conference of Tourism and Information \& Communication Technologies, Málaga, Spain, 10-11 October 2018; pp. 266-281, ISBN 978-84-09-05554-8. Available online: http:/ / turitec.com/wp-content/uploads/2018/10/TURITEC2018-proceedings.pdf (accessed on 15 October 2018).

45. Campesino Fernández, A.-J.; Ramajo Hernández, J.; Rengifo Gallego, J.I.; Sánchez Martín, J.M.; Sánchez Rivero, M. Informe anual Sobre el perfil del Visitante que Acude a las Oficinas de Turismo. Año 2017; Junta de Extremadura: Mérida, Spain, 2018; 148p.

46. INE. Instituto Nacional de Estadística. Available online: http:/ / www.ine.es (accessed on 1 September 2018).

47. Extremadura Regional Government (Junta de Extremadura). Available online: http://www. turismoextremadura.com (accessed on 3 September 2018).

48. National Geographic Institute. (IGN). Available online: http:/ / centrodedescargas.cnig.es/CentroDescargas / buscador.do (accessed on 10 April 2018).

49. Ronquillo Melcio, A. Estadística Aplicada al Sector Turístico: Técnicas Cualitativas y Cuntitativas de Análisis Turístico; Ramón Areces: Madrid, Spain, 1997; 168p, ISBN 9788480042437.

50. Montiel, A.; Rius, F.; Barón, F. Elementos Básicos de Estadística Económica y Empresarial; Prentice Hall: Madrid, Spain, 1997; 448p, ISBN 84-89660-20-4.

51. Parra López, E.; Calero García, F.J. Estadística para Turismo; Mc Graw-Hill: Madrid, Spain, 2007; 306p, ISBN 978-84-481-5666-4.

52. Shoval, N.; Raveh, A. Categorization of tourist attractions and the modeling of tourist cities: Based on the co-plot method of multivariate analysis. Tour. Manag. 2004, 25, 741-750. [CrossRef]

53. Lew, A.M. Modeling Tourist Movements: A Local Destination Analysis. Ann. Tour. Res. 2006, 33, 403-423. [CrossRef]

54. Díez Santo, D. Flujos turísticos y dinámicas de complementariedad territorial: La promoción en los destinos litorales de Alicante. Papers de Turisme 2006, 40, 67-91.

55. Lozano, S.; Gutiérrez, E. A complex network analysis of global tourism flows. Int. J. Tour. Res. 2018, 20, 588-604. [CrossRef] 
56. Leco Berrocal, F.; Mateos Rodríguez, A.; Pérez Díaz, A. Estudio de la demanda del turismo en el parque nacional y reserva de la biosfera de Monfragüe. Cuadernos de Turismo 2015, 35, 231-257. [CrossRef]

57. De Juan Alonso, J. El turismo ornitológico: Concepto y mercados. Referencias al destino Extremadura. Estudios Turísticos 2006, 169-170, 165-182.

58. López Rodríguez, E.; Leco Berrocal, F.; Mateos Rodríguez, A. Patrimonio natural y turismo en el Parque Nacional de Monfragüe. In Sustainability Dilemmas. Transdisciplinary Contributions to Integrated Cultural Landscape management; Oosterbeek, L., Quagliuolo, M., Caron, L., Eds.; Arkeos: Maacâo, Portugal, 2016; pp. 503-518. ISBN 978-989-99131-2-7.

(C) 2018 by the authors. Licensee MDPI, Basel, Switzerland. This article is an open access article distributed under the terms and conditions of the Creative Commons Attribution (CC BY) license (http://creativecommons.org/licenses/by/4.0/). 